\title{
Scenarios of Land-Use Change in Protected Forest of Wosi Rendani Manokwari District, West Papua, Indonesia
}

\author{
Mahmud $^{1,3^{*}}$, Wahyudi ${ }^{1}$, Heru Joko Budirianto ${ }^{2}$, Bambang Nugroho $^{1}$ \\ ${ }^{1}$ Faculty of Forestry, Papua University, J1. Gunung Salju, Amban, West Manokwari, \\ West Papua, Indonesia 98314 \\ ${ }^{2}$ Study Program of Biology, Faculty of Mathematics and Natural Science, Papua University, Jl. Gunung Salju, Amban, West \\ Manokwari, West Papua, Indonesia 98314 \\ ${ }^{3}$ Study Program of Forestry, Faculty of Forestry, Gadjah Mada University, Yogyakarta, Indonesia, 55281
}

Received September 19, 2016/Accepted March 27, 2017

\begin{abstract}
Protected forests have drawn international attention. This research aims to determine scenarios of land-use change in Protected Forest of Wosi Rendani (PFWR). The study was conducted using land evaluation approach to land unit, determination and alternative land use change, based on the potential and the level of threat for PFWR. The results showed that PFWR should remain as a protected forest although the total score of forest modeling was 130. This forest serves to protect soil, water, and danger from floods and landslides. This region has springs, caves, and waterfalls, which can be further developed into eco-tourism and environmental services. As a city forest, PFWR makes Manokwari's weather cooler, enhances the quality of air, reduces environmental pollution, and adds catchment areas. As a community forest, PFWR has forest plants, agricultural crops and fruits, in which people are only allowed to take flowers, fruits, and seeds they have planted. As a buffer zone, PFWR serves as a buffer to reduce population pressures on the forest area or village surrounding the area with high interaction by integrating conservation and economic interests of the surrounding community. As cultivation and settlement, PFWR has three settlements, namely Soribo, Kentestar, and Ipingoisi, 4 settlements outside PFWR namely Tanah Merah Indah, Ajoi, Buton, Mako Brimob, as well as plots of land owned by developers such as Bank Arfindo, Lumintu, Irman Jaya, and Suntari. The final scenario of the land use change in PFWR depends on the policy of local and central government.
\end{abstract}

Keywords: policy, scenario of land use, protected forest, West Papua, Indonesia

*Correspondence author; email: mahmud_thia@yahoo.co.id,ph./fax:+ +62-986-21106

\section{Introduction}

In addition to serving as the lungs of the city, Protected Forest of Wosi Rendani (PFWR) maintains water supplies to meet the needs for water in Manokwari City. As a result, the decree of Governor Number 118/GIB/1969 stipulates it as a hydrological protected forest (MoF 2008). However, it poses problems until the present time because it is only designated by the Governor and has not been stipulated by the Indonesian Ministry of Environment and Forestry. According to Ekawati et al. (2011), protected forests have drawn regional and international attention regarding the considerable importance of the protected forests. However, forest damage occurs in some areas, for example in West Java the rate of deforestation is $23,341-33,951$ ha year ${ }^{-1}$ which results in the formation of critical land (Ekawati 2010). In 1997, protected forests in Manokwari decreased from 300.65 ha to 251.5 ha. The latest data, according to Ministry of Forestry (2014), indicate that PFWR remains only 86.24 ha, which has changed into settlements, agricultural areas, and offices.

The designation of West Papua Province as a conservation province is difficult to realize if the problems existing in protected forests and conservation areas are not immediately resolved. Sinery et al. (2014) state that the problems of protected forests include: excavation, land grabbing, opening residential areas, land clearing by burning, shifting cultivation, loss of boundary, enclave (settlements and land ownership), opening the area for roads, street paving, and soil erosion. As a matter of fact, protected forests serve to protect water and soil in the region and the vicinity. Subarna (2010) and Pitopang (2012) argue that factors that influence the community to work on the land in protected forests include economic pressure, motivation to have land, and minimum number of forest security officers.

In reality, the government is less successful in managing a number of protected and conservation areas due to the absence of policies, but the inability to implement a number of policies, in addition to the limitations and constraints of the field. Limitations include knowledge, scarcity of information, and personnel with poor skills and poor institutions to manage the area. Moreover, problems in protected forest management and conservation areas have 
not received positive response from the public. Therefore, the government should immediately determine appropriate land use in PFWR. This research aims to determine the changes in land use and appropriate alternative designation. It is expected that the results of the research can be taken into consideration by local and central government to immediately determine a definitive status so that the management will be clearer and more focused.

\section{Methods}

The research was conducted at the Soil Laboratory, the Planning and Forest Management Laboratory, the Conservation and Environmental Laboratory, and the PFWR area. Data consisted of land units, number of villages, community identity, benefits of plants, and potential of plant species (trees, horticultural plants, multi-purpose tree species/MPTS). Materials consisted of PFWR maps, thematic maps, soil samples taken from field surveys, computer with Arc GIS 3.3, and Microsoft Office.

Alternative land use change was determined based on the potentials and the levels of threat in PFWR. The potentials of the area include flora, fauna, eco-tourism, and environmental services. Meanwhile, the levels of threat include location of PFWR around settlements, enclave, PFWR in Manokwari City, shifting cultivation, and degradation and deforestation of PFWR. The suitability of land for protected areas was determined based on the Decision of the President of the Republic of Indonesia Number 32 of 1990 concerning Management of Protected Areas, Criteria and Procedures for the Establishment of Protected Areas and the Government Regulation Number 44 of 2004 concerning Forest Planning. Directions of land use function are based on the scoring results from each unit of land. Land parameters include land slope (weight of 20), type of soil and erosion sensitivity (weight of 15), and rain intensity (weight of 10). The results are the direction for area function, that if the total score is $>175$, the area will be classified into a protected area, the total score of 125-175 into a buffer zone, and the total score of $<125$ into an area of cultivation and settlement (Decision of the President of the RI, Number 32 of 1990).

\section{Results and Discussion}

Government policies that do not favor the PFWR have made a considerable impact on deforestation and forest degradation. For instance, a policy on opening of a new road of Esau Sesa at the beginning of 1990 in east side of PFWR has caused damage and decrease in forest areas as shown in Table 1

Natural potentials Natural potentials in PFWR include caves, springs, waterfalls, flora, and fauna (Tables 2, Table 3). Flora in PFWR includes native and exotic plants (Table 3). There are also animals such as wild boar, possum, squirrels, bats, birds, reptiles, and insects. This cave is very beautiful. This cave is shaped like eyes, with a width of six m, a height of three $\mathrm{m}$, and a length of $500 \mathrm{~m}$. In the cave exit there is a water pipe used as a source of drinking water by a water company. At the mouth of the cave, four pipes are installed, two pipes to the water company and the rest for local communities. Currently, water flow used for the water company is only $10 \ell \mathrm{s}^{-1}$ from the total water flow of $448 \ell \mathrm{s}^{-1}$. Droplets of water from cave wall will add and maintain the water flow from the cave. Areas in the cave of PFWR should remain protected so as to maintain the springs.

There are three waterfalls near the cave with a width of between two to three $\mathrm{m}$ and a height of two $\mathrm{m}$. These waterfalls are very clean and clear making them suitable for bathing for tourists. Located close to each other, these waterfalls can be developed into limited tourist object and attraction. The most suitable development of these waterfalls is ecotourism in which the number of tourists and visiting group is limited. In the region there are three locations of springs, which was a material consideration in the appointment of PFWR based on the decree of the Governor of West Irian Jaya No. 118/GIB/1969 as a hydrological protected forest which served to prevent erosion, regulate water system, and maintain soil fertility.

Soils in the forest area are classified into red-yellow podzolic soils. The characteristics of the soils are highly leached soils, parent material in the form of siliceous sedimentary rocks, marl, sandstone, clay, and stone. Redyellow podzolic soils (ultisol) covers a vast area in the world that still have to be developed as an agricultural land. In general, water in the soil is adequately available because the forest is located in an area with high rainfall and agricultural areas belonging to primitive farmers. Although people surrounding PFWR usually practice shifting cultivation, physical and chemical properties of the soils are not good.

Table 1 Deforestation and degradation PFWR

\begin{tabular}{cccl}
\hline Year & Good (ha) & Damaged (ha) & \\
\hline 1969 & 331.78 & - & $\begin{array}{l}\text { In the map results are not reflected boundaries } \\
\text { Residential areas gardens etc. }\end{array}$ \\
1991 & 321.28 & 10.50 & Based on the report on the activities of the minutes of the forest community garden \\
2003 & 76.74 & Based on land cover maps overlaid with a map of the results of 2003 year \\
2008 & 243.59 & $\begin{array}{l}\text { Based on the results of bounds by the Department of Forestry orientation Manokwari District } \\
\text { in 2008 }\end{array}$ \\
2014 & 86.19 & Based on field data obtained by the research \\
\hline
\end{tabular}


Table 2 Potential springs on PFWR

\begin{tabular}{|c|c|c|c|c|c|}
\hline River & Elevation & $\begin{array}{l}\text { Water discharge } \\
\text { utilized PDAM } \\
\qquad\left(\ell \mathrm{s}^{-1}\right)\end{array}$ & $\begin{array}{c}\text { Water } \\
\text { discharge } \\
\text { available } \\
\left(\ell \mathrm{s}^{-1}\right)\end{array}$ & $\begin{array}{l}\text { Water discharge } \\
\text { utilized people } \\
\qquad\left(\ell \mathrm{s}^{-1}\right)\end{array}$ & $\begin{array}{c}\text { Water } \\
\text { discharge } \\
\text { not utilized } \\
\left(\ell \mathrm{s}^{-1}\right)\end{array}$ \\
\hline Springs Dingin & 7 & 30 & 206 & - & 176 \\
\hline Springs Rendani 1 & 46 & 10 & 15 & - & 5 \\
\hline Springs Rendani 2 & 74 & 10 & 448 & 3 & 435 \\
\hline Springs Kentek & 8 & - & 96 & 11 & 85 \\
\hline Total & & 50 & 765 & 14 & 701 \\
\hline
\end{tabular}

Table 3 Plants endemic species, introduce, croping, and medicinal plants

\begin{tabular}{|c|c|c|c|}
\hline Species endemic & Spesies introduce \& exotic & Cropping & Medicinal plants \\
\hline Pometia pinnata & $\begin{array}{l}\text { Intsia } \text { sp., Octomeles } \\
\text { sumatrana } \text { sp., } \\
\text { Dixoxylum } \mathrm{sp.,} \\
\text { Pimeliodendron sp., Pterygota } \\
\text { sp., } \\
\text { Elaeocarpus sp., } \\
\text { Palaquium } \mathrm{sp} ., \\
\text { Celtis sp., } \\
\text { Evodia } \text { sp., } \\
\text { Tectona grandis, } \\
\text { Cananga } \text { sp., } \\
\text { Albizia falcataria } \text { sp., } \\
\text { Calyandra } \text { sp., }\end{array}$ & $\begin{array}{l}\text { Nephelium lappaceum, Capsicum frutescens } \\
\text { L, Solanum lycopersicum, Gnetum gnemon } \\
\text { Durio zibethinus, Artocarpus heterophyllus, } \\
\text { Mangifera indica, Eugenia jambos, Lancium } \\
\text { domesticum, Ipomoea batatas, Carica } \\
\text { papaya, Musa paradisiaca, Capsicum sp., } \\
\text { Manihot utilissima, Zea mays, Pastinaca } \\
\text { sativa, Leucaena leucocephala, Ipomoea } \\
\text { batatas L }\end{array}$ & $\begin{array}{l}\text { Imperata cylindrica, Piper } \\
\text { aduncum, Smilax sp., Psidium } \\
\text { guajawa, Glocidium sp., } \\
\text { Philantus reticulatus, } \\
\text { Archagelesia flava, Dianela } \\
\text { ensifolia, Fhotos scandes, } \\
\text { Adenanthera pavonia, Morinda } \\
\text { citrifolia, Oriochiderubescens, } \\
\text { Callophilum inophilum, } \\
\text { Dendrocnide macrostigma, } \\
\text { Inocarpus fagifer, Ficus septica, } \\
\text { Ficus nodosa, Lunasia amara, } \\
\text { Alstonia scholaris, } \\
\text { Endospermum moluccanum. }\end{array}$ \\
\hline
\end{tabular}

Sources: Sinery et al. (2015)

According to Harjowigeno (2010), ultisols usually gives a good production in the first few years because nutrients in the surface soils collected through a cycle process has not been exhausted. The use of forest soil fertility can be maintained due to recycling process. Bases are leached into the underground, absorbed by roots of forest plants, and returned to the surface through autumn leaves. When forests are cleared, the annual crops or weeds are not able to recycle the bases (nutrients) because the roots are not deep.

Steep topography affects the amount of rainfall, air, temperature, and wind speed. A striking difference in topography will result in differences in the amount of rainfall; in general, a higher place will have high rainfall but low air temperature, while a lower place will have rather low rainfall and relatively high temperature (Asdak 2010). Rain that falls on a rather steep area will trigger erosion and landslide if such area is open used for agriculture and settlement. As a result, water will easily reach surface soil. Raindrop will break down soil aggregates into smaller particles.

Topography of the north side is steep slope $(25-45 \%)$ located after $320 \mathrm{~m}$ (observation point 7-11) from the boundary markers of PFWR. Meanwhile, very steep slope $(>45 \%)$ is located after $500 \mathrm{~m}$ (observation point 17-24) from the boundary markers. Soribo Village is located after the observation point 24 . Topography of the middle side steep slope (25-45\%) located after $200 \mathrm{~m}$ (observation point 4 ), and very steep ( $>45 \%$ ) located after $600 \mathrm{~m}$ (point of observation 20-22) from the boundary markers. To the south side only 10 observation points, given after the $10^{\text {th }}$ entrance point of the Headquarter of Mobile Brigade Corps (Mako Brimob). Topography of the south side is steep (25-45\%) located after $1,600 \mathrm{~m}$ (observation point 3-5) from the boundary markers of PFWR (Sinery et al. 2014). Overall, topography of PFWR has the slope value of $21.19 \%$, which is classified into grade three or rather steep slope.

Precipitation is the input of water on Earth's surface. The distribution and intensity of precipitation affects soil absorption. At the beginning of the rain, water will be easily absorbed by the soil. However, if the rain has saturated, water will flow from the soil surface to the flat slope on a particular place. Based on climate data from the Bureau of Meteorology, Climatology and Geophysics Region V, 
Meteorology Station Class III of Manokwari, average precipitation for the 20 years $(2003-2012)$ is $4,625.9 \mathrm{~mm}$. The highest precipitation in 2012 is $3,288 \mathrm{~mm}$, while the lowest precipitation in 2003 is $1,472 \mathrm{~mm}$, with an average rainfall of $2,312.95 \mathrm{~mm}$. The highest precipitation intensity in 1994 was 17.97, the lowest in 2008 and 2010 by 7.2 with an average precipitation of 12.86 .

PFWR is perceived as an asset by society and government. As much as 36 respondents who had been interviewed $(64.17 \%)$ showed positive perceptions of local community-based management and only a small portion showed neutral/not responding $(10.56 \%)$ and negative perceptions $(25.27 \%)$. Respondents had positive perceptions (64.17\%) of local community-based management because the protected forest is located around residential communities and non-natives. Owners of customary rights realized that if the protected forest is damaged due to landslides, for example, it will cause damage to land, forests and environment of the local community and surrounding areas. PFWR has brought considerable benefits in which they can earn a living by cultivating agricultural crops and fruits. Therefore, people consciously maintain and participate in the government programs such as the National Movement for Forest and Land Rehabilitation (GNRHL).

Only $10.56 \%$ of respondents expressed neutral/not giving comments on local community-based management. They did not provide answers because they might not understand the questions in detail, their education levels are low, and they do not care about PFWR. Meanwhile, there were $25.27 \%$ of the respondents who had negative perceptions of the local community-based management. The groups who disagree are especially those of headmen, chiefs, and educated people. They argued that there should be compensation for protected forest land to owners of customary rights/chiefs. They felt marginalized by the presence of migrants from Java, Sulawesi, Ambon, Sumatra, and Borneo.

Alternative land use PFWR Appropriation of land is an effort in planning land use in an area that includes zoning for the specialization of certain functions, for example, functions of settlements, commerce, industry, protected areas, conservation areas, fields, farms, plantations, airports, etc. The planning of land use is strongly associated with the potentials to use the supporting land so that disasters such as floods and landslides will not occur. Five important alternatives of land-use change in PFWR are as follows:

\section{Protected forest}

- Springs: PFWR has potentials including springs, land, environmental services, flora, and fauna. Although the results of the field research indicated a total score of 130 , or it should be made as a buffer zone, the decree of the Governor of Irian Jaya Barat dated on August 15, 1969 No. 118/GIB/1969 designated PFWR as a hydrological forest because Manokwari city hit by drought. There are four springs in the forest area as shown in Table 2.

- Ecotourism and environmental services: Environmental services are natural products of protected forest such as beautiful views, clear water, fresh, cool, and clean air. PFWR has potential environmental services/ecotourism such as waterfalls, ponds, springs, and caves. Customary rights owners and their families are invited to promote such potentials. The promotion includes tourist attractions, available facilities, accessibility, and information about other tourist destination adjacent to the location (Ngadiono 2004).

- Waterfall: The customary right owner and the family are invited to manage the waterfall including planning, utilization, and supervision. The waterfall is managed under the authority of the Tourism Department of Manokwari District. Currently, waterfall located in the area Prafi is quite far, while waterfall located in the city should be promoted through written media, printed media, radio, television, and tourism bureaus.

- Pond: Natural pond in the city can only be found in PFWR. Currently, the pond is only used by local community for swimming and washing clothes. There is a box provided for those who swim and wash clothes in order that they pay appropriately. If it is well managed by involving customary right owners, it will attract more visitors and tourists, which will increase community welfare and local government revenue.

- Cave: Cave can be made into ecotourism. Ecotourism is a form of tourism that is very close with conservation principles. Therefore, ecotourism is very precise and efficient in maintaining the integrity and originality of the ecosystem in the pristine area. Moreover, ecotourism can improve nature conservation due to the pressure and demands of nature lovers. If the cave and waterfall have been popular and known, local community will be busy providing parking areas, various food, crafts, tour guides, and traditional guesthouses. In addition, visitors will come and increase local revenue. As a result, local community economy will be empowered and increased (Ekawati et al. 2011; Kitamura 2013). Similarly, increased income will make economic growth of the community sustainable (Yeni et al. 2007).

2 Urban forest

In accordance with the Government Regulation Number 47 of 1997 concerning National Spatial Planning, PFWR can be determined as a city forest based on the following consideration:

- In PFWR there are residential areas including villages of Ipingoisi, Kentestar and Soribo and outside the village area including villages of Tanah Merah Indah, Ajoi, Buton, and Mako Brimob area.

- The protected forest area has many multi-layered and stratified structures (Table 3). According to Dahlan (2004) the structure of the city forest should be built in the form of multi-layered and stratified stand, vertically or horizontally, as in the structure of natural forests.

- The forest is located within the city and its vicinity and only $5 \mathrm{~km}$ from the district and provincial capitals.

- PFWR is formed from a community of plants on a plain in compact form, line form or a combination of compact and line form.

- Plants in PFWR are endemic and exotic (Table 3).

- In addition to the forest plants, fruit plants have been developed in accordance with the plan of the Head of the 
Forestry Department of Manokwari District. Manokwari as a city of education and fruits will be realized soon if all elements of society support the program. It is expected in the future that Manokwari will have abundant fruits.

In accordance with the Regulation of the Minister of Forestry No. 63 of 2002, urban forest aims to improve and maintain microclimate and aesthetic value, absorb water, create balance and harmony of the physical environment of the city, and support biodiversity. It is possible that PFWR serves as a city forest because many people come to Manokwari from Java, Sulawesi, Kalimantan, and Sumatra.

By making PFWR as a city forest, Manokwari's weather becomes cooler, carbon will be highly sequestrated, and air quality remains good. People who moved to Manokwari make forest land diminishing because government and many people built houses, offices, factories, business places, markets, etc. Therefore, the existence of forest in the city will add the beauty of Manokwari city, water catchment areas, and biodiversity.

Floods frequently struck Manokwari City in 2002 until 2013 and the largest occurred in 2012. Some believed that it was due heavy rainfall and the opening of PFWR. Since 2013 until now flood-stricken areas have declined as result of the strict prohibition imposed on felling trees and constructing buildings in PFWR. Having a total score of 130 and located at an elevation of $210 \mathrm{~m}$ asl, PFWR receives terrible threat if it rains. Moreover, if the forest is cleared away and used as settlements, there will be runoff, soil removal, and increased water discharge on three rivers in PFWR. Accordingly, by making PFWR a city forest, water will be absorbed by soils, soils remains in place, and water discharge will be relatively stable so that floods will no longer occur.

\section{Community forest}

Forestry development paradigm has changed from wood to ecosystem-oriented outcomes that emphasize communitybased forest management (Devi et al. 2010; Nugroho 2011). This approach has placed the community to manage and maintain the existence of the forest. Hansen (2011) argues that strengthening local community rights is a part of forest management policy reform. Similarly, Larson (2010) states that recognizing indigenous peoples may implicate in strengthening local community rights. Strong capacity (Anderson et al. 2013; Kitamura et al. 2013) is one of the important indicators in achieving sustainable forest governance. By accommodating community activities in the forest, planting crops such as multipurpose tree species will improve local economy. Community forest is a state forest of which its utilization is primarily intended to empower local community through optimal, fair and sustainable use of forest resources while maintaining the sustainability of forest functions and environment (Regulation of Minister of
Forestry No. P.34Menhut-II/2002). From the aforementioned purposes, it is possible to make PFWR a community forest, provided that there are many types of forest plants (endemic and exotic), fruits and medicinal plants as shown in Table 3 .

According to Sinery et al. (2015), there are 20 medicinal plants used by local community to treat 21 types of diseases. Those diseases include diabetes, ulcers, high blood pressure, pneumonia, malaria, warts, kidneys, low blood pressure, rheumatism, uric acid, cancer, blurry eyes, swine scabies, arrow wound, dirty substances, diarrhea, deep vein thrombosis, spine, kidney stones, strengthening stamina, and strengthening hip. As shown in Table 3, some types of plants are planted and others grow wildly. Horticultural cultivation, non-timber forest products, and multi-purpose tree species have been developed. In 2012 the Forestry Department of Manokwari District provided grafted fruit plants for free of charge, so that the plant is expected to fruit rapidly, have sweet taste and be quickly sold in the market.

Communities inhabiting inside PFWR are villages of Ipingoisi, Kentestar, Soribo and outside the area are Tanah Merah Indah, Ajoi, Buton, and Mako Brimob area. They are only allowed take non-timber forest products such as fruits, flowers, rattan, bamboo, honey, sap, and mushroom. As a result, the conservation of forest and environment will be well-maintained.

\section{Regions of buffer}

The results of the field study of PFWR indicated a total score of 130, which means that it should be made as a buffer zone. Buffer zone serves as a buffer to reduce population pressures on the area in the villages or areas with high interaction by integrating conservation and economic interests of the surrounding community.

Based on the total score of 130 (Table 4), PFWR should not be made as a protected forest but a forest that serves as a buffer or limited production forest. The function of such buffer zone can be realized optimally by managing environmental services, and economic value of community land conservation through rehabilitation of degraded land in a system of community forest, people forest, or agroforestry. The development and management should be based on ecological, economic, and social cultural aspects of the communities around the area by dividing the buffer zone into zoning. Buffer forest serves to support life so that its role becomes important when the environment starts to change from shifting and friction between species in the forest community (Sinery et al. 2015).

Zoning in PFWR is then divided into three, namely green lane, interaction lane, and cultivation area. The composition of plant species developed in each lane is adjusted to the distance from boundary, zoning, and land so as not to affect

Table 4 Referral land use on PFWR

\begin{tabular}{llccc}
\hline Criteria & The results & Class & Weight & Score \\
\hline Slope (\%) & 21.9 & 3 & 20 & 60 \\
The type of soil & Podsolic/ultisol & 4 & 15 & 60 \\
Rain intensity $\left(\mathrm{mm} \mathrm{hh}^{-1}\right)$ & 12.86 & 1 & 10 & 10 \\
\hline Total & & & 130 \\
\hline
\end{tabular}


the area. The development of food crops, vegetables, fruits, medicines, and timber in agricultural forestry systems has economic value and is carried out in an ecologically integrated manner in order to preserve genetic resources of plants and wildlife and to conserve land and water. Bismark et al. (2008) shows that forest, plays very important roles in human and animal life that can be understood from hydrological cycle. Basically, it serves to maintain the balance between human life, forests, and other living things that also influenced by abiotic creatures. Such functions can be achieved if the forest is maintained continuously. Another fact, according to The World Bank, indicates that 900 million people in 100 countries face the problem of desertification (forest desertification) caused by complex interactions among physical, biological, political, social, cultural, and economic factors with a loss of US $\$ 42.3$ billion year ${ }^{-1}$. Allegedly, in 2025 desertification will be felt by 1.8 billion people because since 1960 more than 1/5 of tropical forests have disappeared and the rate of loss of tropical forests in the 1970 was 11.3 million ha year ${ }^{-1}$ increasing to 15.4 million ha year $^{-1}$ in 1980. In Indonesia, according to the International Union for Natural Conservation (IUCN), the destruction of forests in Indonesia reaches 2.4 million ha year ${ }^{-1}$ and now there is 70 million ha, or only $50 \%$ remaining.

\section{Cultivation and settlements}

In accordance with the Law Number 24 of 1992 concerning Spatial Planning, in general, land use is divided into two, cultivation area and non-cultivation area. Villages in PFWR area are listed in Table 5. The rate of population growth in Manokwari City affects the emergence of new settlements, including those in PFWR. Those settlements started since the opening of a new road of Esau Sesa, in east side of PFWR because the previous road must pass through Rendani Airport. There are three settlements in PFWR area, namely Soribo, Kentestar, and Ipingoisi villages, four settlements and land ownership outside PFWR area are Tanah Merah Indah village, Ajoi Village, and Mako Brimob area as well as plots of land owned by developers like Bank Arfindo, Lumintu, Irma Jaya, and Suntari.

Surprisingly, settlements and land ownership have been certified. It means that the local government seemed to support the shift of PFWR into settlements. Therefore, due to the certification, it is difficult to return to forest conservation. Meanwhile, changes in land use will decrease land cover that will have implications on carbon dioxide emission, climate change, and biodiversity (Basyuni et al. 2015; Prasetyo 2013). Similarly, changes in land use from natural forest to agricultural are proven to have detrimental effect on ecosystem function of dung beetles, especially dung burial activity (Shahabudin 2011).

PFWR area has been used for farming, shifting cultivation and settlement (Table 3 ). PFWR functioning as cultivation and settlement is the worst land use because problems of this land are acid reaction and high $\mathrm{Al}$ content so that plants contain toxic substances and it causes phosphorus fixation and low nutrient content. If PFWR changes into cultivation area, necessary measures to be taken are reducing the acidity of soil and using fertilizer to increase the content of nutrient elements.

According to Nusan et al. (2012), deficiency of one nutrient elements will lead to abnormal growth and development, which then decrease production and quality of results. Management can be properly carried out by applying soil and water conservation technologies, such as terracing, alley cropping, making of mounds, composting, agricultural forestry, circle of crops, etc. According to Asyerem et al. (2012), in addition to being nutrients for plants, compost can also increase resistance to pathogens. Compost is also a good substrate for the growth of a number of microorganisms serving as biological agents so that the application of compost into soils can reduce pathogens attacking plants. Settlements also include offices in PFWR consisting of approximately 86 houses or buildings.

Residential areas and park area grow in line with the increase in population in Manokwari City. From the results of the inventory and identification of boundaries on the ground around a new path, most of residential communities already have certificates or proofs of land ownership, which is incompatible with the function of PFWR. In order to anticipate the development of settlements and clearing parks by the public or by unauthorized individuals so that they do enter the forest area, it needs constructive coordination between relevant agencies by involving community leaders or heads related directly to PFWR. In order that the protected forest remains sustainable in the future, it requires to be stipulated by the Indonesian Ministry of Environtment and Forestry. As a result, it will obtain stronger legal certainty and clear presence.

In addition to PFWR as agricultural land, settlements are another problem that led to the loss of boundary markers. Out of 150 boundary markers (Table 6), 54 has disappeared $(36 \%)$, and 94 are still in good condition (64\%). As much as 33 boundary markers $(61.11 \%)$ disappeared due to land eviction and 21 boundary markers (38.29\%) due to land revocation. Further 150 boundary markers are entirely composed of the 11 outer boundaries and 32 enclave boundaries $(20.67 \%)$. This is due to the opening of settlements and agricultural lands by communities around forest areas as shown in Table 5 and Table 6.

Clearing and shifting cultivation by burning Papuan people have a habit in opening new area by clear-cutting and burning. Burning and shifting cultivation potentially damage forests and the study of Ernawati (1996) on the Mansinam Island indicates that the rate of deforestation is $7.47 \%(25.75$ ha). Such damage worsens because the opened forest lands are left without doing any effort to conserve the soils. Fallow land for 3-10 years causes shrubs grow wildly on the land. Therefore, the shifting pattern not only destroys the forest, but also has threatened forest preservation. Clearing forests and uncontrolled land use have damaged soils, water, and air. Damages on the land where erosion occurs are in the form of chemical and physical soil nutrient losses, increased density and soil penetration resistance, and decreased soil infiltration capacity and ability to hold water. In 1991 there were 400,000 hectares of critical land due to shifting cultivation (Ministry of Forestry 2009)

\section{Conclusion}

The land use change scenarios on PFWR in the order of importance are as follows: the first, PFWR remains as a 
Table 5 Villages are included in the protected forest

\begin{tabular}{|c|c|c|c|}
\hline Village & Village head & Area (ha) & Point coordinates \\
\hline Soribo & Kristian mandacan & \pm 4 & $\mathrm{~S}^{2} 00^{\circ} 52^{\prime 2} 26,7^{\prime \prime}, \mathrm{E} 134^{\circ} 02^{\prime} 24.3^{\prime \prime}$ \\
\hline Kentekstar & Daud mandacan & \pm 4 & S00 $52^{\prime} 06,4^{\prime \prime}, \mathrm{E} 134^{\circ} 02^{\prime} 03^{\prime \prime}$ \\
\hline Ipingoisi & Panus mandacan & \pm 4 & S00052'33,2”, E13402'30.3" \\
\hline Total & & \pm 12 & \\
\hline
\end{tabular}

Source: $\operatorname{MoF}(2014)$

Table 6 The boundary of PFWR

\begin{tabular}{|c|c|c|c|c|}
\hline Location & Boundary & Missing & Good & Description \\
\hline The new road Wosi & $\mathrm{HL} / 26-\mathrm{HL} / 54$ and & 29 & 20 & Land eviction \\
\hline Rendani & $\mathrm{HL} / 55-\mathrm{HL} / 58$ & & & \\
\hline Makobrimob & $\mathrm{HL} / 59-\mathrm{HL} / 62$ & - & 4 & \\
\hline Kali Dingin & HL/63-HL/84 & 4 & 22 & Land eviction \\
\hline Western Forest Protected & $\mathrm{HL} / 1-\mathrm{HL} / 25$ & 21 & 25 & Ground revoked \\
\hline Around Rendani & HL/85-HL/119 & - & 35 & \\
\hline Total & & 54 & 96 & \\
\hline
\end{tabular}

Solfrce: MoF 2014

protected forest, although it has a total score of 130. This forest serves to protect soils, water and danger from floods and landslides. This area has potential springs, caves and waterfalls that can be developed into eco-tourism and environmental services. The second is that Urban forest; the movement of people to the city makes the air hotter, decreases air quality and causes environmental pollution; therefore, the city forest will make environment better and add water catchment areas. The third scenario is community forest; the area has forest plants, agricultural crops and fruits, in which people are only allowed to only take flowers, fruits and seeds they have planted. The fourth is buffer zone; buffer zone serves as a buffer to reduce the population pressures on the area around the village areas or areas of high interact with integrating conservation and economic interests of the surrounding community. The last scenario is cultivation and settlements. There are three settlements in PFWR area including Soribo, Kentestar, and Ipingoisi, four settlements outside PFWR such as Tanah Merah Indah, Ajoi, Buton, and Mako Brimob area as well as plots of land owned by developers such as Bank Arfindo, Lumintu, Irma Jaya, and Suntari.

\section{Recommendation}

Local and central government should immediately establish a definitive status of PFWR so that the management is clearer and more focused.

\section{Acknowledgment}

The authors would like to express his sincere gratitude to the Faculty of Forestry UGM and LPDP for funding the study in 2016. I also would like thank to my colleagues, Heru Joko Budirianto, Piter Gusbager, and students: Tasaruni and Sidik Waskito for their contribution and help especially during the fieldwork for data collection.

\section{References}

Anderson K, Benavides JP, Leon R.2013. Institutional diversity and local forest governance. Journal of Environmental Science \&Policy 36:61-72. https://doi. org/10.1016/j.envsci.2013.07.009.

Asdak C. 2010. Hydrology and management watershed. Yogyakarta: Gajah Mada University Press.

Asyerem F, Dyah M, Bintoro D. 2012. Effect of composite from Ageratum conizoides, Thithonia diversifolia Hemsley A. Grey and waste Sago in chili (Capsicum annum L.). Agrotek 3(2):1-9.

Basyuni M, Lollie APP, Murni MB. 2015. Implication of land-use and land-cover change into carbon dioxide emissions in Karang Gading and Langkat Timur wildlife reserve, North Sumatra, Indonesia. Jurnal Manajemen Hutan Tropika 21(1):25-35. https://doi.org/10.7226/ jtfm.21.1.25.

Bismark M, Sawitri R. 2008. Land-use management and community forest in buffer zone of mount Ceremai National Park, Majalangka District, West Java. Info Hutan 5(4):317-327.

Dahlan EN. 2004. Membangun Kota Kebun (Garden City) 
Bernuansa Hutan Kota. Bogor: IPB Press.

Devi IN, Rizal H, Kusumedi P. 2010. Study the implementation of protection forest management rules: case study in Pangkep and Maros Regencies, South Sulawesi Province. Jurnal Analisis Kebijakan Kehutanan 7(3):195-200.

Ekawati S. 2010. The study working relationship between institutions in the management of protected forest in the era of autonomy. Jurnal Analisis Kebijakan Kehutanan 7(3):11-22. https://doi.org/10.20886/jakk.2011.8.2.132151.

Ekawati S, Hariadi K, Hardjanto, Haryatno DP, Dodik RN. 2011. Policy making process of authorities among levels of government in the protected forest management and its implementation in the regency level. Jurnal Analisis Kebijakan Kehutanan 8(2):132-151.

Ernawati. 1996. Based on the Extent and Intensity of Damage in the Form Mansinam Island Manokwari District. Manokwari: Faculty of Agriculture, Cendrawasih University.

[GoIR] Government of Republic Indonesian. 1992. UU No. 24 Tahun 1992 tentang Penataan Ruang. Jakarta: Ministry of Public Work.

[GoIR] Government of Republic Indonesian. 2004. UU No.44 Tahun 2004 tentang Perencanaan Hutan. Jakarta: Ministry of Forestry.

[GoIR] Government of Republic Indonesian. 2002. Peraturan Pemerintah No.63 Tahun 2002 tentang Hutan Kota. Jakarta: Peraturan Pemerintah Republik Indonesia 2002.

[GoIR] Government of Republic Indonesian. 2002. Peraturan Pemerintah No.34 Tahun 2002 tentang Hutan Kemasyarakatan. Jakarta: Departemen Kehutanan 2002.

Harjowigeno S. 2010. Soil Science. Jakarta: Academic Presindo.

Hansen CP. 2011. Forest law compliance and enforcement: The case study of on farm timer extraction in Ghana. Journal of Environmental Management 92(3):575-586. https://doi.org/10.1016/j.jenvman.2010.09.021.

Kitamura K, Clapp RA. 2013. Common property protected areas: community control in forest conservation. Journal of Land Use Policy 34:204-212. https://doi.org/10.1016/ j.landusepol.2013.03.008

Larson AM. 2010. Making the 'rules of the game' constituting, ecological knowledge and market structure in South-Eastern Zimbabwe. Journal of Ecological Economics 70(3):454-461. https://doi.org/10.1016/ j.ecolecon.2010.09.036.

[MoF] Ministry of Forestry. 2008. Hutan Lindung Wosi Rendani. Manokwari: Forestry Research and
Development Agency Ministry of Forestry.

[MoF] Ministry of Forestry. 2009. Land Without Fuel Preparation for Planting. Jakarta: Forestry Research and Development Agency Ministry of Forestry.

[MoF] Ministry of Forestry. 2014. Hutan Lindung Wosi Rendani. Manokwari: Ministry of Forestry.

Ngadiono. 2004. 35 Tahun Pengelolaan Hutan Indonesia Refleksi dan Prospek. Bogor: Penerbit Yayasan Adi Sanggoro.

Nugroho B. 2011. Land right of community forest plantation policy: analysis from institutional perspective. Jurnal Manajemen Hutan Tropika 17(3):111-118.

Nusan S, Isahak M, Irnanda AFD. 2012. Some soil chemical properties and growth of sweet potato (Iomea batatas $\mathrm{L}$ as an effect of the application of crandalite extract, humic acid fraction and potassium and mineral soil of Warmare. Agrotek 3(2):19-29.

Permenhut. 2007. Permenhut Number. P. 37 Tahun 2007 tentang Hutan Kemasyarakatan. Jakarta Ministry of Forestry.

Pitopang R. 2012. Impact of forest disturbance on the structure and composition of vegetation in tropical rainforest of Central Sulawesi, Indonesia. Biodersitas 13(4):178-189. https://doi.org/10.13057/biodiv/ d130403.

Prasetyo LB. 2013. Land use, climate change and biodiversity modeling: Perspectives and applications 2011, 512 pages. Jurnal Manajemen Hutan Tropika 19 (3):8-17.https://doi.org/10.7226/jtfm.19.3.211.

[Rop] Resolution of President 1990. Pengelolaan Kawasan Lindung tentang Kriteria dan Tata Cara Penetapan Hutan Lindung. Jakarta: Pemerintah Republik Indonesia.

Shahabudin. 2011. Effect of land use change on ecosystem function of dung beetles: experimental evidence from Wallace Region in Sulawesi, Indonesia. Biodiversitas 12 (3):177-181.

Sinery AS, Mahmud. 2014. Fungsi kawasan dan strategi pengelolaan hutan lindung Wosi Rendani Kab. Manokwari. Agrifor 12(2):131-140.

Sinery AS, Rusdi A, Yohanes YR, Hans FZP.2015. Potensi dan Strategi Pengelolaan Hutan Lindung Wosi Rendani. Yogyakarta: Deepublish.

Subarna T. 2011. Factors that influence social to cultivate land in protected forest. Jurnal Penelitian Sosial dan Ekonomi Kehutanan 8(2):34-42.

Yeni I, Innah HS. 2007. A study on the implementation of forest village community establishment in Papua. Jurnal Penelitian SoSial dan Ekonomi Kehutanan 4(1):73-91. 